\title{
Determinants Of Success In International Involvement Of Large U.S. Corporations
}

M. Anaam Hashmi, Minnesota State University, Mankato, USA

\begin{abstract}
The findings of this study help to identify factors explaining success in international operations of large U.S. corporations. Successful foreign direct investment (FDI) and continuous involvement of large U.S. corporations is crucial for economic development of a country and social uplifting of many citizens of the world. Data were collected on selected U.S. corporations' perception of the success variables in their international operation. Results indicate that large market size, geographical diversification, and low production/operating cost are the three most important success determinants of international operations.
\end{abstract}

Keywords: Foreign Direct Investment; Development; U.S. Corporations; Successful International Ventures; Globalization

\section{INTRODUCTION}

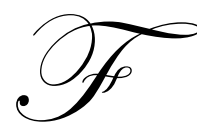

oreign direct investment (FDI) is defined as investment in a foreign country where investors enjoy substantial ownership and control (Eiteman, et al, 2010). Much research has focused on determinants of FDI, but there is limited empirical work identifying differences between successful and unsuccessful FDI activities. Few multinational investors and their host countries demonstrate better history of successful international ventures, while other multinational investors and host countries have struggled to succeed. The globalization trend has forced most large U.S. corporations to invest billions of dollars in international markets, and these large U.S. corporations seek ways to improve profitability and success of these investments. A successful corporation is most likely to continue investing in a particular country, and these investments are crucial for economic development and better living conditions for their citizens.

Another interesting piece of the puzzle is the availability and usefulness of FDI related informational resources to U.S. corporations. Those U.S. corporations interested in investing at an international location need guidance and micro data to ensure success of their multimillion dollar investments. Numerous U.S. marketing research and consulting entities offer guidance and pertinent data to domestic corporations, but their services come with a hefty price tag. The purpose of this study is to identify key FDI related success factors for large U.S. corporations; therefore, large U.S. corporations can be profitable in their current and future operations.

\section{LITEREATURE REVIEW}

Bernal (2010) analyzed Chinese economic relationships and FDI in Caribbean Community (CARICOM) member countries, concluding that Chinese FDI motives are economic as well as political. CARICOM countries are very small; therefore, after joining the economic bloc they were considered "as relatively large markets" and hence attractive for Chinese FDI. Another benefit may be geographic diversification for Chinese enterprises, since they do not wish to invest in any one region or continent. Large market size, geographic diversity, and political relationships were the key success factors for Chinese FDI in CARICOM region countries. Buckley et al. (2005) analyzed the diversion of FDI from Association of South East Asian Nations (ASEAN) member countries to China. Chinese market size and future growth were key success factors for diversion of FDI to China. Buckley et al (2005) also concluded that after joining the World Trade Organization (WTO), China may attract more FDI because China will be forced to follow free-market policies and U.S. governmental agencies can offer subsidies to interested U.S. corporations. 
Kentor and Jorgenson (2010) examined the role of FDI and foreign subsidiaries in the economic growth of lesser developed countries between 1970 and 2000. This landmark research project concluded that overall growth of foreign subsidiaries between 1970 and 2000 has a positive effect on economic growth in most of the lesser developed countries. Furthermore, political corruption and poor corporate governance were found to discourage FDI in these less developed countries. Blalock and Gertler (2008) studied Indonesian manufacturing companies and technological progress as a result of increased FDI. The Indonesian study found strong relationship between FDI and productivity gains and lower price in domestic suppliers of foreign corporations. Furthermore, the benefits of FDI were also observed in domestic corporations not in direct partnership with the foreign corporations. The productivity gains and technology transfer were in several economic sectors and ensuring development in the Indonesian economy.

Bayulgen and Ladewig (2004) tested the neo-liberal argument, i.e. a positive relationship exists between democratization process and globalization of economy. Bayulgen and Ladewig empirically tested the theory of FDI performance that is based on political regime type (authoritarian, hybrid, and democratic regimes) and constraints on a host-country's business executives. Democratization seemed to help foreign corporations and FDI flow, but the relationship was not always positive. Neumayer (2005) established a relationship between FDI flow and success with bilateral investment treaties (BITs) between host and home countries. This finding sheds light on the importance of political cooperation along with widely known economic factors. Domestic political systems and political relationships between host and home countries are considered to be important determinants of successful FDI activities.

Amal et al (2009) studied FDI flow from three Latin American countries and found exchange rate and globalization of the home country to be key variables in FDI success. A growing and globalized country not only attracts investment but also provides favorable conditions for investment outflow to other countries. Grigoriadis and Kamaras (2008) undertook a major task of analyzing FDI in Turkey during the past decade. During 2002-2007, Turkey attracted more FDI than the earlier 20 years, and this success is attributed to democratic and market based policies of the Turkish government. Additional causes of increased and successful FDI include the globalization of the Turkish economy and conscious efforts by the Turkish government to diversify its source of FDI inflows from Europe, Asia, and Arabian Gulf countries. Finally, foreign investors thrived in Turkey because the government's purpose aligned with the priorities of Turkey's business elite, a group that became a powerful advocate of stabilization and globalization.

Perkins-Rodrigues (2005) examined FDI in the Brazilian telecommunication industry during 1997-2004. Perkins-Rodrigues downgraded the importance of prior investment experience in predicting a new successful investment. Prior experience did not guarantee success in new ventures, and success was attributed to other institutional and political factors such as business regulations and political philosophy of the country. Nadolska and Barkema (2007) studied 1038 foreign acquisitions of 25 firms over a period of more than three decades, and concluded that prior acquisition was not necessary a major success factor of the new acquisition decisions. Nadolska and Barkema (2007) found that country-specific knowledge, such as local culture and suitable entry mode were the key determinants of success in international acquisitions. Phillips (2010) reported the newly published study of foreign direct investment in 87 countries. Phillips (2010) found a positive relationship between FDI and domestic business regulations, concluding "... restrictive laws and red tape discourage foreign direct investment, and many countries with such laws have not done as well economically. Large markets such as China's were the exception." This study highlighted many reasons of FDI but did not explain as why some investments are successful and others are not.

The reviewed literature identified several success factors for a successful FDI strategy. None of the studies cited have identified usefulness of most of the FDI related success factors for U.S. corporations. After literature review, the following research question is formulated to help large U.S. corporations succeed in their future FDI ventures.

Research Question: What criteria or variables are investigated by large U.S. corporations while evaluating success of international operations? 


\section{RESEARCH METHODOLOGY}

A questionnaire was mailed out to a sample of globally operating American corporations selected from the Fortune 500 list. Fortune 500 corporations are well known in the world and operate in diversified industries. All corporations that operated primarily in the domestic sector were identified based on their percentage of foreign sales to total sales and were removed from the sample. A total of 422 questionnaires were mailed out by name to the Chief Executive Officers of these corporations. The Chief Executive Officers were in the best position to forward the questionnaire to the appropriate people in their organizations. The questionnaire included questions related to the corporation's foreign direct investment related success factors. A self-addressed stamped envelope was enclosed to improve the response rate. As an incentive to the respondents, they were promised summary data after the conclusion of the project.

A seven-point Likert scale was used to measure responses for the research question \# 1 and research question \# 2. Due to change of address, 11 questionnaires were not delivered. Seventy-nine usable responses were returned for data analysis, making the response rate of this study $19.22 \%$.

To examine the research question a list of 12 variables defining success in international operations was compiled, after reviewing the literature and visiting four U.S. corporations. These variables are studied by most U.S. corporations in evaluation of their international operations, and the participating corporations were asked to rank each variable's importance in defining success of their international operations.

\section{DATA ANALYSES}

Some international involvement activities and foreign direct investments (FDIs) by U.S. corporations are successful while other fails to yield results, and there are myriad reasons for success or failure of these activities. After literature review twelve of the possible success variables were selected, and participating U.S. corporations were requested to rank the usefulness of these factors in the corporation's overall international involvement and FDI activities. The mean scores of these variables' ranking (on a scale of 1 to 7 ) are presented in Table 1 along with standard deviation. The variables are listed is descending order, according to the mean importance score.

Participants reported the most important variable regarding the success of international involvement and FDI activities is "large market size." Large market size allows U.S. corporations to customize their products and services and still compete on price with the host country's corporations. That is why many small and medium sized countries are considering economic integration (Bernal, 2010). Large market size of an economic bloc may attract more foreign direct investment. The second and third most important variables reported were "geographical diversification" and "low production and operating cost." Through geographical diversification, a corporation can minimize losses due to business cycles and regional business crises. For instance, if an American company has maintained most of its international operation in one country, the company would obviously suffer losses if the host country goes through economic hardship. U.S. companies can improve likelihood of their success by expanding their operations and FDI activities to other viable geographical locations. Also, increased political risk and business cost can be offset if the host country's resources allow lower production and operating cost.

The fourth most important variable for determining success in international operation was "free market policies of host countries." Corporations based in the U.S. have been accustomed to the free market business environment at home and usually perform well in a free market economic system, where host governments cannot stifle their creativity and flexibility. "Product diversification" and "democratic system in the host country" were ranked as the fifth and sixth most important variables for a successful international operation. Democratic systems are usually practicing free-market systems with limited government interference; thus U.S. corporations are not subject to anti-business regulations. At the same time, a large number of countries in the Middle East and Asia (including China) are non-democratic but they are still attractive to the U.S. corporations. It seems that investors are more concerned with free-market economic policies than democratic political regimes.

A surprising finding was the low importance of "economic incentives offered by the host country" and "U.S. economic incentives / financing," two variables that were ranked seventh and tenth by the surveyed U.S. 
corporations. Two U.S. government subsidized programs, "EX-IM Bank / FCIA insurance programs" and "OPIC insurance programs," were ranked lowest by respondents. These findings should be reviewed by policymakers in deciding future financial allocations to these programs. U.S. government-subsidized insurance programs and economic incentives may encourage U.S. corporations' international involvement and FDI activities, but long-term success is based on fundamental economic and structural variables. Similarly, the host country's subsidies and economic incentives may encourage foreign corporations to invest, but these incentives do not guarantee success in future operations. Possibly, these subsidized U.S. and host country's government programs may be benefiting only a few very large U.S. corporations while leaving behind other mid-sized enterprises.

The two most important variables' (large market size and geographical diversification) mean scores have low variability (low standard deviation), suggesting that most responding corporations consider these two variables equally important. EX-IM Bank / FCIA insurance program importance scores received the most variance, indicating a few corporations consider these programs to be highly important while others found them worthless.

Table 1: Importance of Variables Defining Success in International Operations

\begin{tabular}{|l|l|c|c|}
\hline & Success Variables & Mean Score & S.D. \\
\hline 1 & Large market size & 5.89 & 0.857 \\
\hline 2 & Geographical diversification & 5.68 & 0.657 \\
\hline 3 & Low production and operating cost & 5.29 & 1.153 \\
\hline 4 & Free market policies of host countries & 5.05 & 1.574 \\
\hline 5 & Product diversification & 4.78 & 1.053 \\
\hline 6 & Democratic system in the host country & 4.45 & 1.464 \\
\hline 7 & Economic Incentives offered by the host country & 4.43 & 1.193 \\
\hline 8 & Following industry trends & 4.24 & 1.403 \\
\hline 9 & Favorable exchange rate & 3.99 & 1.255 \\
\hline 10 & U.S. economic incentives / financing & 3.72 & 1.173 \\
\hline 11 & EX-IM Bank / FCIA insurance programs & 3.26 & 1.721 \\
\hline 12 & OPIC insurance programs & 2.47 & 1.252 \\
\hline
\end{tabular}

Note: $\quad$ Mean scores are derived from a 7 point Likert scale where $1=$ not important and $7=$ extremely important. $\mathrm{N}=76$.

\section{SUMMARY AND CONCLUSIONS}

The results of this study have shed new light on the factors explaining success in international involvement and FDI activities for large U.S. corporations. The dominant success factors were large market size of the host country and geographical diversity of international involvement, which minimizes the influence of economic cycles and regional idiosyncrasies. Some of the other dominant success factors were low production/operating cost, free market policies of host countries, and product diversification. Subsidized programs and economic incentives provided by governments (U.S. and host country) were not considered useful by the surveyed large U.S. corporations. There is no compelling evidence to burden tax-payers because these subsidized programs are not high on the list of success factors. Subsidized programs and economic incentives are not benefiting large U.S. corporations and may not be contributing to economic development of the host country. The findings of this study may help U.S. corporations to improve their profitability and reduce failure rates of their international operations. A successful corporation is expected to continue their international operation, possibly contribute to economic development of the host country, and uplift economic status their citizens.

Finally, this study answered many questions as discussed in the data analyses section, but the responses raised new questions or brought to light possible areas for further probing. This study can be refined by breaking down findings based on industry, level of international involvement, and the geographical region of international involvement, thus corporations can learn more about themselves and their industry. 


\section{AUTHOR INFORMATION}

Dr. M. Anaam Hashmi is a professor of international business and finance at the Minnesota State University, Mankato, USA. Dr. Hashmi has held several leadership positions and published over seventy applied research papers. His current areas of interest are carbon market, political risk management, and foreign direct investment. E-mail: m.hashmi@mnsu.edu

\section{REFERENCES}

1. Amal, Mohamed. 2009. "Strategies and Determinants of Foreign Direct Investment (FDI) fromDeveloping Countries: Case Study of Latin America," Latin American Business Review, April-September 2009, Vol. 10, Issues 2/3, p: 73-94.

2. Bayulgen, Oksan and Jeffrey Ladewig. 2004. "Dictators and Democrats: The Political Source ofSuccess in Attracting Foreign Direct Investment.” Midwest Political Science Association Annual Meeting, Chicago, Illinois, p: 1-40.

3. Bernal, Richard. 2010. "The Dragon in the Caribbean: China-CARICOM Economic Relations,"Round Table, June 2010, Vol. 99, Issue 408, p: 281-302.

4. Blalock, Garrick and Paul Gertler. 2008. "Welfare Gains from Foreign Direct Investment Through Technology Transfer To Local Suppliers." Journal of International Economics. March 2008, Vol. 74, Issue 2, p. 402-421.

5. Buckley, Peter, Jeremy Clegg, Adam Cross, and Hui Tan. 2005. "China’s Inward Foreign Direct Investment Success: Southeast Asia in the Shadow of the Dragon," The Multinational Business Review, Spring 2005, Vol. 13, Number 1, p: 3-31.

6. Eiteman, David, Arthur Stonehill, and Michael Moffett. 2010. Multinational Business Finance, $12^{\text {th }}$ edition, Prentice Hall, New York.

7. Grigoriadis, Ioannis and Antonis Kamaras. 2008. "Foreign Direct Investment in Turkey: Historical Constraints and the AKP Success Story," Middle Eastern Studies, January 2008, Vol. 44, No. 1, p: 53-68.

8. Kentor, Jeffrey and Andrew Jorgenson. 2010. "Foreign Investment and Development: An Organizational Perspective." International Sociology. May 2010, Vol. 25, No. 3, p. 419-441.

9. Minton-Eversole, Theresa. 1993. "Global Training: How to Design a Program for the Multinational Corporation” Training \& Development, May 1993, Vol. 47 Issue 5, p: 107-108.

10. Nadolska, Anna and Harry Barkema. 2007. "Learning to Internationalize: The Pace and Success of Foreign Acquisitions," Journal of International Business Studies, Vol. 38, p: 1170-1186.

11. Neumayer, Eric. 2005. "Do Bilateral Investment Treaties Increase Direct Investment to Developing Countries," World Development, October 2005, Vo. 33, Issues 10, p: 1567-1585.

12. Perkins-Rodrigues, Susan. 2005. "Institutional Environment Relatedness and Foreign Investment Failures in the Brazilian Telecommunications Industry," Academy of Management Best Conference Papers, 2005.

13. Phillips, Michelle. 2010. "World Bank Study: Direct Investment Tied to Success," The Washington Times, July 7, 2010. 
NOTES 